\title{
FAKTOR RESIKO DAN ANGKA KEJADIAN BERAT BADAN LAHIR RENDAH (BBLR) DI RSUP DR. MOHAMMAD HOESIN PALEMBANG TAHUN 2014
}

\author{
Intan Kumalasari ${ }^{1}$, RM.Suryadi Tjekyan ${ }^{2}$, M. Zulkarnain ${ }^{2}$ \\ ${ }^{1}$ Poltekkes Kemenkes Palembang \\ ${ }^{2}$ Fakultas Kesehatan Masyarakat Universitas Sriwijaya
RISK FACTORS AND THE INCIDENCE OF LOW BIRTH WEIGHT IN DR. MOHAMMAD HOESIN PALEMBANG HOSPITAL 2014

\begin{abstract}
Background: Low Birth Weight $(L B W)$ is still a major public health problem. The high incidence of LBW may affect the quality of human resources in the future, since babies born with LBW may also cause an increased risk of permanent disability, cognitive impairment and other chronic health problems in the future. Identification of $L B W$ risk factors is important in mediating the health consequences of $L B W$ after birth and also in reducing the incidence of $L B W$. This study aims to the risk factors and the incidence of $L B W$ in Dr. $M$. Hoesin Palembang Hospital.

Methods: This study was a retrospective analytic survey with cross sectional design, using secondary data, collected from medical records of Dr. M. Hoesin Palembang Hospital from January $1^{\text {St }}$ to December $31^{S t}$, 2014. the sample were 1582 of whole birth from a population that met the inclusion criteria. Data were analyzed by univariate, bivariate with chi square and multivariate test with multiple logistic regression.

Results: The incidence of $L B W$ were 19.6\%. The result of bivariate analysis showed significant relationship between gestational age $(p=0,000 ; O R=77,055)$, twin pregnancy $(p=0,000 ; O R=21,387)$, eclampsia $(p=$ $0,002 ; O R=3,310)$, preeclampsia $(p=0,010 ; O R=1,836) H b(p=0.014 ; O R=1,668)$ and education $(p=0,044$; $O R=1,640$ ) with $L B W$. Gestational age is the most dominant factor causing $L B W$ after controlled by other variables.

Conclusion: The incidence of LBW in Dr. M. Hoesin Palembang Hospital in 2014 was still high with the most dominant factor is Gestational age. Need to develop a model of early detection of $L B W$ at the community level by reference to the risk factors found in every health care unit in Palembang
\end{abstract}

Keywords: low birth weight, risk factors, incidence of low birth

\begin{abstract}
ABSTRAK
Latar Belakang: Berat Badan Lahir Rendah (BBLR) sampai saat ini masih menjadi masalah kesehatan masyarakat yang utama. Tingginya angka kejadian BBLR dapat mempengaruhi kualitas sumber daya manusia di masa depan, karena bayi yang lahir dengan BBLR juga dapat menyebabkan peningkatan risiko kecacatan permanen, gangguan kognitif dan masalah kesehatan kronis lainnya dikemudian hari. Identifikasi faktor risiko BBLR adalah penting dalam menengahi konsekuensi kesehatan BBLR setelah lahir dan juga dalam mengurangi angka kejadian BBLR. Penelitian ini bertujuan untuk mengetahuai faktor risiko dan angka kejadian BBLR di RSUP Dr. M. Hoesin Palembang

Metode: Penelitian ini menggunakan survey analitik retrospektif dengan rancangan cross sectional, menggunakan data sekunder dari Instalasi rekam Medik RSUP Dr. M. Hoesin Palembang periode 1 Januari31 Desember 2014.

Sampel diambil dari populasi yang memenuhi kriteria inklusi sebanyak 1582. Pengambilan sampel dengan teknik total sampling. Data dianalisis secara univariat, bivariat dengan uji chi square dan multivariat dengan regresi logistik ganda.

Hasil Penelitian: Angka kejadian BBLR sebesar 19,6\%. Hasil analisis bivariat menunjukkan bahwa ada hubungan yang signifikan antara usia kehamilan $(p=0,000 ; \mathrm{OR}=77,055)$, kehamilan ganda $(p=0,000$; $\mathrm{OR}=21,387), \quad$ eklampsi, $\quad(p=0,002 ; \mathrm{OR}=3,310), \quad$ preeklamsi $\quad(p=0,010 ; \mathrm{OR}=1,836) \quad$ kadar $\mathrm{Hb}$ $(p=0,014 ; \mathrm{OR}=1,668)$ dan pendidikan $(p=0,044 ; \mathrm{OR}=1,640)$ dengan kejadian BBLR. Usia kehamilan merupakan faktor yang paling dominan menyebabkan BBLR setelah dikontrol variabel lain.
\end{abstract}

Alamat Koresponding: Intan Kumalasari, Poltekkes Kemenkes Palembang, Jl. Jend. Sudirman, KM 3,5 No. 1365 Samping Masjid AshShofa, email : kumalasariintan74@gmail.com 
Kesimpulan: Angka kejadian BBLR di RSUP Dr. M. Hoesin Palembang tahun 2014 masih tinggi dengan faktor risiko yang utama adalah usia kehamilan. Perlu dikembangkan model deteksi dini BBLR di tingkat komunitas dengan merujuk pada faktor risiko yang ditemukan pada setiap unit pelayanan di Kota Palembang

Kata Kunci: Low birth weight, faktor risiko, angka kejadian

\section{PENDAHULUAN}

Berat Badan Lahir Rendah (BBLR) sampai saat ini masih menjadi masalah kesehatan masyarakat yang utama, diperkirakan $15-20 \%$ dari semua kelahiran di seluruh dunia adalah BBLR yang mewakili lebih dari 20 juta kelahiran per tahun. ${ }^{1}$ Meskipun ada variasi dalam prevalensi BBLR di setiap negara, namun hampir 95,6\% dari mereka berada di negara berkembang atau negara dengan sosial ekonomi rendah., ${ }^{2,3,4,5}$ WHO mengestimasi $60-80 \%$ penyebab kematian bayi baru lahir paling dominan khususnya di empat minggu pertama kelahirannya dikarenakan BBLR, ${ }^{6,7}$ yaitu berisiko 40 kali lebih besar mengalami kematian pada masa perinatal dengan angka kematian neonatal secara global meningkat 20 kali lipat lebih besar pada bayi BBLR dibandingkan bayi dengan berat badan normal. ${ }^{1}$

Lebih dari $50 \%$ beban global BBLR terjadi di Asia, dengan insiden terbesar di Asia Selatan (26\%) dimana satu dari empat bayi baru lahir adalah dengan berat kurang dari 2.500 gram. $^{8}$ Insiden BBLR di tujuh Negara Asia Tenggara berkisar 7-21\%, dimana insiden di Indonesia 7\% (masih berada di atas Vietnam 5\%), namun jauh lebih baik dibandingkan dengan Burma 9\%, Timor Leste $10 \%$, Kamboja $11 \%$, Laos $15 \%$ dan Philipina $21 \%$. $^{9,10}$

Berat badan lahir rendah (BBLR) adalah hasil dari hambatan pertumbuhan intrauterine, kelahiran prematur atau kombinasi patofisiologi keduanya. ${ }^{2}$ Ada banyak faktor yang berkontribusi dalam kejadian BBLR, diantaranya faktor ibu, janin dan plasenta. $^{11}$ Krammer telah mengidentifikasi 43 faktor potensial BBLR, namun tidak berarti semua faktor harus hadir di daerah tertentu, masing-masing faktor bervariasi dari satu daerah ke daerah lain, tergantung pada faktor geografis, sosial ekonomi dan budaya. ${ }^{12}$

Penelitian di Maharashtra India, menunjukkan bahwa berat badan lahir rendah berkaitan dengan faktor sosial ekonomi ibu dan keluarga, pendidikan ibu, pekerjaan, paritas, perawatan antenatal, status gizi ibu, berat badan ibu sebelum hamil $(<45 \mathrm{~kg})$, tinggi badan $<145 \mathrm{~cm}$, riwayat kebidanan yang buruk, konsumsi tembakau, anemia, hypertensi dalam kehamilan, ${ }^{12}$ dan preeklampsia/eklampsia. ${ }^{13}$ Ricketts dkk. menyatakan bahwa faktor risiko bayi BBLR adalah kehamilan kembar (lebih dari satu janin), ibu merokok. Ibu yang memiliki berat badan yang rendah sebelum hamil, ibu atau janin stres, infeksi, dan kekerasan terhadap wanita semasa hamil. ${ }^{14}$ Salah satu tantangan utama dalam mengukur insiden BBLR adalah kenyataan bahwa lebih dari separuh anak-anak di dunia belum ditimbang saat dilahirkan, terutama beberapa daerah di Afrika dan Asia Tenggara, kebanyakan bayi yang dilahirkan di rumah dan tidak diukur, selain itu juga banyak kelahiran di rumah sakit atau klinik kesehatan yang kecil tidak dilaporkan dalam angka yang resmi yang dapat mengakibatkan prevalensi BBLR di bawah estimasi. ${ }^{15}$ World Health Assembly telah menargetkan pengurangan angka kejadian BBLR sebesar 30\% pada tahun 2025. Hal ini berarti ada penurunan relatif $3,9 \%$ per tahun antara tahun 2012$2025 .^{16}$ Oleh karena itu penting untuk memiliki data prevalensi yang akurat pada populasi dan faktor risiko BBLR, sehingga dapat merencanakan pola perawatan khusus untuk pencegahan dan pengelolaan bayi BBLR di unit bersalin sehingga angka kesakitan dan kematian neonatal dan perinatal dapat berkurang secara signifikan. ${ }^{17}$

Indonesia (seperti halnya data dunia mengenai insiden BBLR) secara umum belum 
mempunyai angka untuk BBLR yang diperoleh berdasarkan survai nasional. Proporsi BBLR ditentukan berdasarkan estimasi yang sifatnya sangat kasar, yaitu berkisar antara 7-14\% selama periode 1999$2000{ }^{18}$ Tahun 2013 prevalensi BBLR di Indonesia $10,2 \%$, dengan rentang variasi 7,2$16,9 \%$, dimana prevalensi terendah di Sumatera Utara $(7,2 \%)$ dan tertinggi di Sulawesi Tengah (16,9\%), sementara Sumatera Selatan berkisar $9,8 \%$ yang merupakan urutan ke-11 terendah BBLR di Indonesia. ${ }^{19}$

Profil Kesehatan Provinsi Sumatera Selatan tahun 2012 melaporkan kejadian BBLR hanya $1 \%,{ }^{20}$ sedangkan di Palembang dilaporkan hanya terdapat 497 kejadian BBLR dari 30.614 kelahiran hidup atau sekitar $1,74 \%{ }^{21}$ Akan tetapi angka tersebut belum mencerminkan kondisi sebenarnya yang ada di masyarakat, karena belum semua berat badan bayi yang dilahirkan dapat dipantau oleh petugas kesehatan, khususnya yang ditolong oleh dukun atau tenaga non kesehatan lainnya.

Rumah Sakit Umum Pusat Dr. Mohammad Hoesin Palembang, merupakan salah satu rumah sakit untuk rujukan kasuskasus obstetrik yang utama di kota Palembang. Data yang diperoleh dari RSUP Dr. Mohammad Hoesin Palembang dari tahun 2007-2011 secara berurutan menunjukkan angka kejadian BBLR sebesar 4,3\%, 9,5\%, $13 \%, 14,8 \%$ dan 17,7\% (Medical Record RSUP Dr. Mohammad Hoesin Palembang, 2011). Berdasarkan data diatas, maka insiden BBLR di RSUP Dr. Mohammad Hoesin Palembang 5 tahun terakhir cenderung mengalami peningkatan.

Tingginya angka kejadian BBLR dapat mempengaruhi kualitas sumber daya manusia dimasa depan, karena bayi yang lahir dengan BBLR juga dapat menyebabkan peningkatan risiko kecacatan permanen, gangguan kognitif dan perkembangan saraf, ${ }^{22}$ gangguan dalam belajar, memiliki IQ yang lebih rendah, dan berisiko putus sekolah serta masalah kesehatan kronis lainnya dikemudian hari. ${ }^{23,24}$ Oleh karena itu identifikasi faktor risiko BBLR adalah penting dalam menengahi konsekuensi kesehatan BBLR setelah lahir dan juga dalam mengurangi prevalensi BBLR. Tujuan penelitian ini adalah mengetahui faktor risiko dan angka kejadian BBLR di RSUP Dr. M. Hoesin Palembang.

\section{METODE}

Penelitian ini menggunakan desain penelitian survey analitik retrospektif dengan pendekatan cross sectional. Populasi penelitian adalah seluruh kelahiran di RSUP Dr. Mohammad Hoesin Palembang periode 1 Januari-31 Desember 2014 dengan menggunakan data sekunder dari instalasi rekam medik. Sampel diambil dari populasi yang memenuhi kriteria inklusi sebanyak 1582 kelahiran. Pengambilan sampel dengan teknik total sampling. Variabel dependen penelitian ini adalah berat bayi lahir rendah dan variabel independen yang diamati adalah umur ibu, usia kehamilan, paritas, kadar hemoglobin, riwayat abortus,riwayat preeklampsi dan eklampsi, riwayat diabetes mellitus, kehamilan ganda, jenis kelamin janin, pendidikan ibu dan pekerjaan ibu.

Analisa data dilakukan untuk mengetahui hubungan antara karakteristik Ibu dengan kejadian BBLR. Analisa data pada penelitian ini menggunakan analisis univariat, bivariat dengan chi-square dan multivariat dengan regresi logistik ganda menggunakan metode Backward LR untuk melihat faktor resiko yang paling berpengaruh dengan kejadian BBLR, kemudian melakukan interpretasi hasil analisis dan membuat model persamaan.

\section{HASIL PENELITIAN}

Hasil penelitian didapatkan 19,6\% kelahiran dengan BBLR dan $80,4 \%$ tidak BBLR. Distribusi kejadian BBLR selengkapnya ditampilkan pada Tabel 1 berikut: 
Tabel 1.

Distribusi Responden Berdasarkan Kejadian BBLR

\begin{tabular}{ccc}
\hline \multirow{2}{*}{ Berat Badan Lahir } & \multicolumn{2}{c}{ Jumlah } \\
\cline { 2 - 3 } & n & $\mathbf{\%}$ \\
\hline Normal $(\geq 2500$ gr $)$ & 1272 & 80,4 \\
BBLR $(<2500$ gr $)$ & 310 & 19,6 \\
\hline Jumlah & $\mathbf{1 5 8 2}$ & $\mathbf{1 0 0 \%}$ \\
\hline
\end{tabular}

Karakteristik responden pada penelitian ini meliputi: umur ibu, usia kehamilan, paritas, kadar hemoglobin, riwayat abortus,riwayat preeklampsi dan eklampsi, riwayat diabetes mellitus, kehamilan ganda, jenis kelamin janin, pendidikan ibu dan pekerjaan ibu, selengkapnya ditampilkan pada Tabel 2. berikut :

Tabel 2.

Distribusi Frekuensi Beberapa Faktor Risiko BBLR

\begin{tabular}{|c|c|c|}
\hline \multirow[b]{2}{*}{ Karakteristik Ibu } & \multicolumn{2}{|c|}{ Jumlah } \\
\hline & $\mathbf{n}$ & $\%$ \\
\hline \multicolumn{3}{|l|}{ Usia Ibu } \\
\hline$<20$ Tahun & 132 & 8,3 \\
\hline 20-35 Tahun & 1193 & 75,4 \\
\hline$>35$ Tahun & 257 & 16,2 \\
\hline \multicolumn{3}{|l|}{ Usia Kehamilan } \\
\hline Preterm & 313 & 19,8 \\
\hline Aterm & 1258 & 79,5 \\
\hline Postterm & 11 & 0,7 \\
\hline \multicolumn{3}{|l|}{ Paritas } \\
\hline Primipara & 634 & 40,1 \\
\hline Multipara & 894 & 56,5 \\
\hline Grandemultipara & 54 & 3,4 \\
\hline \multicolumn{3}{|l|}{ Kadar hemoglobin } \\
\hline$<11$ gr/dL (Anemia) & 732 & 47,7 \\
\hline$>11$ gr/dL (Tidak Anemia) & 803 & 52,3 \\
\hline \multicolumn{3}{|l|}{ Riwayat Abortus } \\
\hline Ada & 170 & 10,7 \\
\hline Tidak Ada & 1412 & 89,3 \\
\hline \multicolumn{3}{|l|}{$\overline{\text { Preeklampsi }}$} \\
\hline Ada & 427 & 27 \\
\hline Tidak Ada & 1155 & 73 \\
\hline \multicolumn{3}{|l|}{ Eklampsi } \\
\hline Ada & 76 & 4,8 \\
\hline Tidak Ada & 1506 & 95,2 \\
\hline \multicolumn{3}{|l|}{ Kehamilan ganda } \\
\hline Ganda & 64 & 4 \\
\hline Tunggal & 1518 & 96 \\
\hline \multicolumn{3}{|l|}{ Jenis kelamin } \\
\hline Laki-laki & 801 & 50,6 \\
\hline Perempuan & 781 & 49,4 \\
\hline \multicolumn{3}{|l|}{ Diabetes Mellitus } \\
\hline Ada & 4 & 0,3 \\
\hline Tidak Ada & 1578 & 99,7 \\
\hline \multicolumn{3}{|l|}{ Pendidikan Terakhir } \\
\hline TS (Tidak Sekolah) & 6 & 0,4 \\
\hline SD & 121 & 8,0 \\
\hline SMP & 176 & 11,6 \\
\hline SMA & 1177 & 77,4 \\
\hline D3 & 15 & 1,0 \\
\hline $\mathrm{S} 1$ & 25 & 1,6 \\
\hline \multicolumn{3}{|l|}{ Pekerjaan } \\
\hline Ibu Rumah Tangga (IRT) & 1456 & 92 \\
\hline Mahasiswa & 2 & 0,1 \\
\hline Pelajar & 7 & 0,4 \\
\hline Buruh & 3 & 0,2 \\
\hline Petani & 21 & 1,3 \\
\hline Swasta & 51 & 3,2 \\
\hline Wiraswasta & 13 & 0,8 \\
\hline
\end{tabular}




\begin{tabular}{lcc}
\hline Guru & 9 & 0,6 \\
Tenaga Kesehatan & 4 & 0,3 \\
PNS & 16 & 1,0 \\
\hline
\end{tabular}

Tabel 2. menunjukkan sebagian besar usia ibu berada di rentang umur 20-35 tahun $1193(75,4 \%)$, Usia ibu saat melahirkan termuda 15 tahun dan tertua 51 tahun. Usia kehamilan aterm (cukup bulan) 1258 (79,5\%). Usia kehamilan termuda 22 minggu dan tertua 43 minggu. Paritas ibu sebagian besar multipara $894(56,5 \%)$. Terdapat $732(47,7 \%)$ ibu dengan kadar $\mathrm{Hb}<11 \mathrm{gr} / \mathrm{dL}$ (anemia) dengan rata-rata kadar $\mathrm{Hb} 10,981$ (95\% CI 10,905-11,057). Kadar $\mathrm{Hb}$ terendah yaitu 4,5
gr/dL dan tertinggi 16,5 g/dL. Sebanyak 170 $(10,7 \%)$ ibu memiliki riwayat abortus, kehamilan dengan preeklampsia sebanyak 427 (27\%), eklampsia $76(4,8 \%)$, riwayat diabetes mellitus sebanyak $4(0,3 \%)$, kehamilan ganda $64(4 \%)$ dan bayi yang dilahirkan berjenis kelamin perempuan sebanyak 781 (49,4\%). Pendidikan ibu sebagian besar adalah SLTA $1177(74,7 \%)$ sementara dilihat dari status pekerjaan, sebagian besar ibu tidak bekerja yaitu 1456 (92\%) sebagai ibu rumah tangga.

Tabel 3.

Analisis Bivariat Faktor yang Mempengaruhi Kejadian BBLR di Rumah Sakit Muhammad Hoesin Palembang

\begin{tabular}{|c|c|c|c|c|c|c|c|c|}
\hline \multirow{3}{*}{ Faktor Risiko } & \multicolumn{4}{|c|}{ Berat Badan Lahir Bayi } & \multirow{2}{*}{\multicolumn{2}{|c|}{ Jumlah }} & \multirow{3}{*}{$p$} & \multirow{3}{*}{$\mathbf{R P}$} \\
\hline & \multicolumn{2}{|c|}{ BBLR } & \multicolumn{2}{|c|}{ BBRN } & & & & \\
\hline & $\mathrm{n}$ & $\%$ & $\mathrm{n}$ & $\%$ & $\mathrm{n}$ & $\%$ & & \\
\hline \multicolumn{9}{|l|}{ Usia Ibu } \\
\hline$<20$ tahun dan $>35$ tahun & 26 & 19,7 & 106 & 80,3 & 132 & 100 & \multirow{3}{*}{$\begin{array}{l}1,000 \\
0,993 \\
0,977\end{array}$} & $1,011(0,643-1,588)$ \\
\hline $20-35$ tahun & 233 & 19,5 & 960 & 80,5 & 1193 & 100 & & \\
\hline$>35$ tahun & 51 & 19,8 & 206 & 80,2 & 257 & 100 & & $1,020(0,727-1,431)$ \\
\hline \multicolumn{9}{|l|}{ Usia Kehamilan } \\
\hline Preterm & 248 & 79,2 & 65 & 20,8 & 313 & 100 & $0,000^{*}$ & \multirow[t]{2}{*}{$74,869(51,45-108,96)$} \\
\hline Aterm & 61 & 4,8 & 1179 & 95,2 & 1258 & 100 & $0,000 *$ & \\
\hline Postterm & 1 & 9,1 & 10 & 90,9 & 11 & 100 & 0,425 & $1,962(0,247-15,577)$ \\
\hline \multicolumn{9}{|l|}{ Paritas } \\
\hline Primipara & 106 & 16,7 & 528 & 83,3 & 634 & 100 & \multicolumn{2}{|l|}{$0,019 *$} \\
\hline Multipara & 188 & 21,0 & 706 & 79,0 & 894 & 100 & $0,041 *$ & $1,326(1,019-1,726)$ \\
\hline Grandmultipara & 16 & 29,6 & 38 & 70,4 & 54 & 100 & $0,028^{*}$ & $2,097(1,128-3,900$ \\
\hline \multicolumn{9}{|l|}{ Kadar Hb } \\
\hline$<11 \mathrm{gr} \%$ (Anemia) & 183 & 25,0 & 549 & 75,0 & 732 & 100 & \multirow[t]{2}{*}{$0,000^{*}$} & 1,861 \\
\hline$>11$ gr\%(Tidak Anemia) & 122 & 15,2 & 681 & 84,8 & 803 & 100 & & $(1,442-2,402)$ \\
\hline \multicolumn{9}{|l|}{ Abortus } \\
\hline Ada & 41 & 24,1 & 129 & 75,9 & 170 & 100 & \multirow[t]{2}{*}{$0,142 * *$} & 1,350 \\
\hline Tidak & 269 & 19,1 & 1143 & 80,9 & 1412 & 100 & & $(0,928-1,966)$ \\
\hline \multicolumn{9}{|l|}{ Preeklampsi } \\
\hline Ada & 104 & 24,4 & 323 & 75,6 & 427 & 100 & \multirow[t]{2}{*}{$0,005^{*}$} & 1,483 \\
\hline Tidak ada & 206 & 17,8 & 949 & 82,2 & 1155 & 100 & & $(1,135-1,938)$ \\
\hline \multicolumn{9}{|l|}{ Eklampsi } \\
\hline Ada & 36 & 47,4 & 40 & 52,6 & 76 & 100 & \multirow[t]{2}{*}{$0,000^{*}$} & 4,047 \\
\hline Tidak ada & 274 & 18,2 & 1232 & 81,8 & 1506 & 100 & & $(2,532-6,468)$ \\
\hline \multicolumn{9}{|l|}{ Diabetes Mellitus } \\
\hline Ada & 2 & 50,0 & 2 & 50,0 & 4 & 100 & \multirow[t]{2}{*}{$0,174 * *$} & 4,123 \\
\hline Tidak ada & 308 & 19,5 & 1270 & 80,5 & 1578 & 100 & & $(0,579-29,388)$ \\
\hline \multicolumn{9}{|l|}{ Kehamilan ganda } \\
\hline $\mathrm{Ya}$ & 51 & 79,7 & 13 & 20,3 & 64 & 100 & \multirow[t]{2}{*}{$0,000^{*}$} & \multirow{2}{*}{$\begin{array}{c}19,070 \\
(10,223-35,573)\end{array}$} \\
\hline Tidak & 259 & 17,1 & 1259 & 82,9 & 1518 & 100 & & \\
\hline Jenis Kelamin & & & & & & & & \\
\hline Perempuan & 162 & 20,7 & 619 & 79,3 & 781 & 100 & 0,284 & 1,155 \\
\hline Laki-laki & 148 & 18,5 & 653 & 81,5 & 801 & 100 & & $(0,901-1,480)$ \\
\hline
\end{tabular}




\section{Pendidikan Ibu}

Pendidikan rendah

(TS, SD, SMP)

Pendidikan tinggi

(S1, D3, SLTA)

Pekerjaan Ibu

Bekerja

(buruh, swasta,dll)

Tidak bekerja

(IRT, Mhs, Pelajar)

\begin{tabular}{|c|c|c|c|c|c|c|c|}
\hline 85 & 28,1 & 218 & 71,9 & 303 & 100 & $0,000 *$ & $\begin{array}{c}1,870 \\
(1,397-2,502)\end{array}$ \\
\hline 210 & 17,3 & 1007 & 82,7 & 1217 & 100 & & \\
\hline 24 & 20,5 & 93 & 79,5 & 117 & 100 & \multirow[b]{2}{*}{0,890} & \multirow[b]{2}{*}{$\begin{array}{c}1,064 \\
(0,667-1,697)\end{array}$} \\
\hline 286 & 19,5 & 1179 & 80,5 & 1465 & 100 & & \\
\hline
\end{tabular}

Keterangan :

* signifikan, $p$ value $<0,05$

** $p$ value $<0,25$

Secara statistik terdapat hubungan signifikan antara usia kehamilan, paritas, kadar HB, preeklampsi, eklampsi, kehamilan ganda dan pendidikan ibu terhadap kejadian BBLR. Tidak ada hubungan signifikan antara usia ibu, diabetes mellitus, jenis kelamin bayi dan pekerjaan ibu dengan kejadian BBLR.

Variabel-variabel kandidat yang memenuhi kriteria kandidat model multivariat adalah variabel yang bermakna secara statistik $(\mathrm{p}<0,05)$ dan variabel yang memiliki nilai $\mathrm{p}<0,25$ meliputi ; usia kehamilan, paritas, kadar $\mathrm{Hb}$, riwayat abortus, riwayat preeklampsi, riwayat eklamsi, diabetes mellitus, kehamilan ganda dan pendidikan ibu. Selengkapnya disajikan dalam Tabel 4. berikut ini:

Tabel 4.

Model Awal dan Akhir Analisis Multivariat Faktor yang Mempengaruhi Kejadian BBLR di Rumah Sakit Muhammad Hoesin Palembang

\begin{tabular}{lccccc}
\hline \multirow{2}{*}{ Variabel } & \multicolumn{3}{c}{ Model awal } & \multicolumn{2}{c}{ Model akhir } \\
\cline { 2 - 6 } & $P_{-}$value & OR(95\%CI) & Koofisien & $P_{-}$value & OR(95\%CI) \\
\hline Usia Kehamilan Ibu & 0,000 & $79.154(51.299-122.133)$ & 4,345 & 0,000 & $77,055(50,276-118,099)$ \\
Kehamilan ganda & 0,000 & $22,222(9,033-54,667)$ & 3,063 & 0,000 & $21,387(8,879-51,515)$ \\
Diabetes Mellitus & 0,468 & $3,374(0,127-89,698)$ & & - & - \\
Eklamsi & 0,003 & $3,200(1,487-6,886)$ & 1,197 & 0,002 & $3,310(1,545-7,088)$ \\
Pre Eklamsi & 0,009 & $1,860(1,167-2,963)$ & 0,608 & 0,010 & $1,836(1,159-2,909)$ \\
Pendidikan Ibu & 0,034 & $1,698(1,040-2,772)$ & 0,495 & 0,044 & $1,640(1,012-2,658)$ \\
Kadar Hemoglobin & 0,014 & $1,663(1,106-2,500)$ & 0,512 & 0,014 & $1,668(1,111-2,504)$ \\
Paritas & 0,475 & $0,856(0,559-1,311)$ & & - & - \\
Riwayat Abortus & 0,570 & $0,833(0,443-1,564)$ & & - & - \\
Constant & 0,000 & 0,025 & $-3,800$ & & 0,022 \\
\hline
\end{tabular}

Hasil analisis multivariat menunjukkan model akhir variabel yang terbukti sangat berpengaruh terhadap kejadian BBLR adalah usia kehamilan, kehamilan ganda, eklampsi, preeklamsi, kadar $\mathrm{Hb}$, dan pendidikan ibu.

Adapun persamaan model persamaan kejadian BBLR sebagai berikut :

Kejadian BBLR = -3,800 + 4,345 (Usia kehamilan) + 3,063 (kehamilan kembar) + 1,197

(eklamsi) + 0,608 (preeklamsi) + 0,512 (kadar Hb)+ 0,495 (pendidikan) 


\section{PEMBAHASAN}

Hasil penelitian diketahui angka kejadian berat badan lahir rendah (BBLR) di RSUP Dr. Mohammad Hoesin Palembang tahun 2014 adalah 19,6\%, lebih tinggi dibandingkan kejadian global $(16 \%),{ }^{1}$ negara berkembang $(19 \%)^{17}$, Indonesia $(10,3 \%),{ }^{19}$ Sumatera Selatan $(9,8 \%),{ }^{19}$ dan Kota Palembang (12,3\%). ${ }^{26}$ Angka ini lebih besar dari target BBLR yang ditetapkan pada sasaran program perbaikan gizi menuju Indonesia Sehat 2010 sebesar 7\%. ${ }^{25}$ Tingginya angka kejadian BBLR dapat dipengaruhi oleh multifaktor, diantaranya usia kehamilan, kadar $\mathrm{Hb}$, preeklampsi, eklamsi, kehamilan ganda dan pendidikan ibu.

\section{Usia Kehamilan}

Hasil penelitian diketahui angka persalinan preterm mencapai $19,8 \%$ dari seluruh persalinan dan $79,2 \%$ nya melahirkan bayi BBLR. Analisis bivariat menunjukkan bahwa usia kehamilan memiliki hubungan yang signifikan dengan kejadian BBLR $(p=0,000 ; \mathrm{OR}=74,869)$ begitu juga pada analisis multivariat dimana usia kehamilan merupakan variabel yang paling berpengaruh terhadap kejadian BBLR $(p=0.000$; $\mathrm{OR}=77,055)$. Hasil penelitian ini selaras dengan penelitian Tjekyan, yang menunjukkan hubungan yang bermakna usia kehamilan dengan BBLR $(p=0,000)$ dengan $\mathrm{OR}=9,482,{ }^{26}$ dan penelitian yang menyatakan usia kehamilan <37 minggu beresiko 3,93 kali mengalami BBLR. ${ }^{27}$ Usia kehamilan pada persalinan adalah penentu paling signifikan dari berat badan bayi baru lahir. Usia kehamilan mempengaruhi pematangan organ dan efektifitas penyaluran nutrisi dan oksigenasi plasenta yang dibutuhkan janin untuk tumbuh optimal. ${ }^{28}$ Pada kehamilan kurang bulan (28-36 minggu) pematangan organ yang belum sempurna dan kurang efektifitas penyaluran nutrisi dan oksigenenisasi membuat pertumbuhan janin tidak optimal, hal tersebut menyebabkan kelahiran prematur dan bayi dengan berat badan lahir rendah. Menurut peneliti berkembangnya peran dan fungsi organ tubuh bayi sejalan dengan usia kehamilan ibu. Semakin matur usia kehamilan maka perkembangan organ tubuh bayi semakin sempurna, sehingga bayi lebih siap untuk bertahan hidup di luar rahim. Kematuran usia kehamilan juga dipengaruhi asupan nutrisi selama kehamilan. Pada setiap tahap proses kehamilan, seorang ibu hamil membutuhkan nutrisi makanan dengan kandungan zat gizi yang berbeda-beda dan disesuaikan dengan perkembangan janin dan kondisi tubuh ibu. Oleh karenanya pemantauan dan pengawasan kondisi ibu di setiap tahap kehamilan sangat diperlukan agar ibu dan bayi terlahir sehat.

\section{Kehamilan Ganda}

Hasil uji bivariat $(p=0,000 ; \mathrm{OR}=19,070)$ dan multivariat $(p=0,000 ; \quad \mathrm{OR}=21,387)$ menunjukkan ada hubungan yang bermakna antara kehamilan ganda dengan kejadian BBLR. BBLR merupakan hasil dari kelahiran prematur dan atau pertumbuhan janin yang buruk. Keduanya umum terjadi pada kehamilan ganda. Pada kehamilan ganda suplai darah ke janin terbagi dua atau lebih untuk masing-masing janin sehingga suplai nutrisi berkurang. Berat badan satu janin pada kehamilan ganda rata-rata 1000 gram lebih ringan dari pada janin kehamilan tunggal. Berat badan bayi yang baru lahir umumnya pada kehamilan ganda $<2500$ gram, pada triplet $<2000$ gram dan untuk kuadruplet $<1500$ gram. Secara teori 60 persen dari kehamilan ganda, $>90$ persen dari kembar triplet, dan hampir semua kelahiran dengan kembar kuadruplet akan mengalami kelahiran prematur, ${ }^{29}$ hal tersebut sesuai dengan hasil penelitian dimana $62,5 \%$ dari kehamilan ganda dan $100 \%$ untuk kehamilan triplet (dengan rentang usia kehamilan 32-35 minggu) mengalami kelahiran prematur dan $79,9 \%$ terlahir dengan kondisi BBLR. Menurut peneliti kehamilan ganda 
memerlukan asupan nutrisi jauh lebih banyak dari kehamilan tunggal. Asupan nutrisi yang tidak terpenuhi akan mempengaruhi tumbuh kembang janin di dalam kandungan. Untuk itu diperlukan tambahan nutrisi yang cukup dan pemeriksaan ANC yang teratur untuk memonitor kehamilan kembar sehingga dapat membantu menurunkan risiko atau komplikasi yang berhubungan dengan kehamilan kembar seperti BBLR.

\section{Riwayat Preeklampsi dan Eklampsi}

Preeklampsi merupakan faktor risiko BBLR dengan angka kejadian $24,4 \%$ dari seluruh persalinan di RSUP Dr. Mohammad Hoesin Palembang. Berdasarkan hasil uji bivariat $(p=0,005)$ dan multivariat $(p=0,010)$ diketahui bahwa ada hubungan bermakna preeklampsi dengan kejadian BBLR. Hasil penelitian ini selaras dengan penelitian Kurniawati yang menunjukkan ada hubungan yang signifikan antara preeklampsia dengan kelahiran BBLR, dimana peluang terjadinya kelahiran BBLR lebih tinggi 3,25 kali daripada tanpa preeklampsia. ${ }^{30}$ Preeklamsia adalah suatu gangguan yang muncul pada masa kehamilan. Umumnya terjadi pada usia kehamilan >20 minggu. Gejala yang umum adalah tingginya tekanan darah, pembengkakan yang tak kunjung sembuh dan tingginya jumlah protein di urin. namun penyebab sesungguhnya masih belum diketahui. Preeklampsia dapat mencegah plasenta mendapat asupan darah yang cukup, sehingga janin dapat kekurangan oksigen dan nutrisi. Hal ini dapat menimbulkan rendahnya bobot tubuh bayi ketika lahir dan menimbulkan masalah lain, seperti kelahiran kurang bulan sampai kematian saat kelahiran (perinatal death). Eklampsi adalah kejang yang menyertai preeklamsia, ibu dengan preeklampsi/eklampsi berisiko 4,09 kali melahirkan bayi BBLR. ${ }^{12}$ Hasil uji bivariat $(p=0,000) \quad$ dan multivariat $(p=0,002)$ menunjukkan ada hubungan bermakna eklampsi dengan kejadian BBLR dengan resiko 4,047 (95\%CI 2,532-6,468) kali lebih besar dari pada persalinan tanpa eklampsi, Angka kejadian eklampsi sebesar 4,8\% dari seluruh persalinan dan $47,4 \%$ nya melahirkan BBLR.

Preeklampsia sering terjadi pada primigravida dan wanita yang memiliki riwayat preeklamsia di keluarganya. Risiko preeklampsia dan eklampsia lebih besar pada wanita yang memiliki banyak anak, wanita hamil usia remaja, wanita hamil di atas usia 40 tahun, wanita dengan tekanan darah tinggi atau memiliki gangguan ginjal sebelum hamil. Karena itu penting melakukan pencegahan terhadap kejadian BBLR dengan mengurangi faktor risiko seperti pendewasaan usia pernikahan dan kehamilan, pemberian suplemen kalsium selama kehamilan untuk wanita dengan asupan kalsium yang rendah efektif dalam mengurangi preeklampsia dan kelahiran prematur serta pemberian antiplatelet (anti pembekuan darah) $<16$ minggu untuk ibu yang berisiko preeklampsia. ${ }^{16}$

\section{Kadar Hemoglobin}

Hasil analisis diperoleh 46,3\% ibu memiliki kadar $\mathrm{Hb}<11 \mathrm{gr} / \mathrm{dL}$ dan $25 \%$ nya melahirkan BBLR. Hasil uji bivariat $(p=0,000) \quad$ dan multivariat $(p=0,014)$ menunjukkan hubungan yang bermakna antara kadar $\mathrm{Hb}$ dengan kejadian BBLR. Ibu hamil dengan kadar $\mathrm{Hb}<11$ berpeluang 1,861 kali lebih besar melahirkan BBLR dibandingkan kadar $\mathrm{Hb}>11$. Hal ini diperkuat dengan hasil penelitian lain yang memaparkan bahwa ibu dengan anemia berisiko 2,54 kali lebih besar untuk melahirkan bayi dengan BBLR. ${ }^{12}$

Kekurangan kadar $\mathrm{Hb}$ pada ibu hamil merupakan salah satu permasalahan kesehatan yang rentan terjadi selama kehamilan, Kadar $\mathrm{Hb}<11 \mathrm{~g} / \mathrm{dl}$ mengindikasikan ibu hamil menderita anemia. Anemia pada ibu hamil meningkatkan risiko kejadian BBLR, risiko perdarahan sebelum dan saat persalinan, 
bahkan dapat menyebabkan kematian ibu dan bayinya jika ibu hamil tersebut menderita anemia berat. Hal ini dapat memberikan sumbangan besar terhadap angka kematian ibu bersalin maupun angka kematian bayi. ${ }^{31}$ Pada keadaanfisiologis kehamilan, konsentrasi $\mathrm{Hb}$ dan eritrosit akan meningkat namun peningkatan tersebut akan melambat pada pertengahan usia kehamilan sehingga konsentrasi $\mathrm{Hb}$ akan menurun sesuai dengan peningkatan volume darah dan menjadi sangat rendah pada bulan kelima dan ketujuh kehamilan, ${ }^{32}$ Data Depkes RI, 2002 menunjukkan bahwa lebih dari 50\% ibu hamil menderita anemia dengan sebagian besar penyebabnya adalah kekurangan zat besi yang diperlukan untuk pembentukan hemoglobin. ${ }^{33}$ Anemia zat besi terjadi karena tidak cukupnya zat besi yang diserap dari makanan sehari-hari guna pembentukan sel darah merah sehingga menyebabkan ketidakseimbangan antara pemasukan dan pengeluaran zat besi dalam tubuh. ${ }^{34}$ Hal ini dapat menyebabkan distribusi oksigen ke jaringan akan berkurang yang akan menurunkan metabolisme jaringan sehingga pertumbuhan janin akan terhambat, dan berakibat BBLR. ${ }^{35}$

Kebutuhan zat gizi khususnya zat besi pada ibu hamil meningkat sesuai dengan bertambahnya umur kehamilan. Apabila terjadi peningkatan kebutuhan zat besi tanpa disertai oleh pemasukan yang memadai maka cadangan zat besi akan menurun dan dapat mengakibatkan terjadinya anemia. Jumlah zat besi yang dibutuhkan pada waktu hamil jauh lebih besar dari wanita yang tidak hamil, hal ini dikarenakan kebutuhan zat besi naik untuk kebutuhan plasenta dan janin dalam kandungan. Faktor lain penyebab anemia diantaranya kurang gizi, penyakit kronis (infeksi dan non infeksi), kemiskinan, keterbelakangan, tingkat pendidikan dan pengetahuan yang rendah, Selain itu faktor ketidaktahuan ibu terhadap kebiasaan konsumsi bahan makanan/minuman tertentu yang dapat menghambat penyerapan zat besi oleh tubuh, yaitu antara lain ibu tidak mengetahui bahwa tablet besi tidak boleh dikonsumsi dengan teh (karena mengandung asam fitat) dapat menghambat penyerapan zat besi oleh tubuh. ${ }^{33,34}$

Menurut peneliti, ibu dengan kondisi hamil harus menjaga asupan nutrisi yang baik agar pertumbuhan dan perkembangan janin optimal. Bila nutrisi ibu hamil tidak terpenuhi maka ibu berisiko mengalami anemia, ancaman yang dapat ditimbulkan oleh anemia pada janin adalah kematian janin, resiko terjadinya abortus, dan berat badan lahir rendah.

\section{Pendidikan Ibu}

Hasil uji bivariat menunjukkan ada hubungan bermakna tingkat pendidikan dengan BBLR $(p=0,000)$, dengan resiko 1,870 kali lebih besar terjadi pada ibu dengan tingkat pendidikan rendah dari pada tingkat pendidikan tinggi, begitu juga dengan hasil mutivariat $(p=0,044)$. Hal ini sejalan dengan penelitian yang menyatakan tingkat pendidikan rendah memiliki risiko 1,919 kali lebih besar untuk melahirkan BBLR dibandingkan ibu hamil dengan tingkat pendidikan tinggi. ${ }^{36}$ Hasil analisis tingkat pendidikan berkaitan dengan luasnya wawasan yang dimiliki oleh seorang ibu. Semakin tinggi tingkat pendidikan maka wawasan yang dimiliki ibu akan semakin tinggi dan memiliki pola pikir yang terbuka untuk menerima pengetahuan baru yang dianggap bermanfaat dalam masa kehamilannya. ${ }^{37}$

Tingkat pendidikan yang dimiliki ibu mempunyai pengaruh kuat pada perilaku reproduksi, kelahiran, kematian anak dan bayi, kesakitan, dan sikap serta kesadaran atas kesehatan keluarga. Latar belakang pendidikan ibu mempengaruhi sikapnya dalam memilih pelayanan kesehatan dan pola konsumsi makan yang berhubungan juga dengan peningkatan berat badan ibu semasa hamil yang pada saatnya akan mempengaruhi kejadian BBLR. Ibu yang berpendidikan 
rendah sulit untuk menerima inovasi dan sebagian besar kurang mengetahui pentingnya perawatan pra kelahiran dan mempunyai keterbatasan mendapatkan pelayanan antenatal yang adekuat dan keterbatasan mengkonsumsi makanan yang bergizi selama hamil. ${ }^{38}$

Hasil akhir model persamaan diperoleh nilai parameter diskriminasi Area Under Curve/AUC sebesar 92\%, artinya peluang kejadian BBLR 92\% dijelaskan oleh variabel usia kehamilan, kehamilan ganda, eklampsi, preeklampsi, kadar $\mathrm{Hb}$ dan pendidikan, sedangkan $8 \%$ nya dijelaskan oleh variabel lainnya yang tidak diteliti. Berdasarkan pemaparan diatas dapat diasumsikan bahwa secara statistik kualitas persamaan model kejadian BBLR tersebut sangat kuat (>90\% $100 \%$ ), Namun menurut peneliti, ada faktor lainnya yang tidak diteliti mempengaruhi terjadinya BBLR, diantaranya kunjungan antenatal dan asupan zat gizi. Hal tersebut tidak peneliti lakukan karena data yang peneliti butuhkan tidak tersedia secara lengkap dalam catatan rekam medik di Instalasi Rumah Sakit Dr.M. Hoesin Palembang.

Menurut peneliti kondisi kesehatan ibu selama kehamilan dapat terpantau dengan baik bila ibu mau melakukan kunjungan antenatal secara rutin minimal 4 kali selama kehamilan, untuk itu optimalisasi pelayanan antenatal secara komprehensif, terpadu dan berkualitas sangat diperlukan agar masalah kesehatan ibu seperti kekurangan nutrisi, rendahnya kadar $\mathrm{HB}$, peningkatan protein urine, gangguan tumbuh kembang janin dan kehamilan dengan komplikasi serta masalah kesehatan/penyakit penyerta kehamilan dapat

\section{DAFTAR PUSTAKA}

1. UNICEF and WHO. Low Birth Weight, Country Regional and Global Estimates. 2004.

https://www.unicef.org/publications/index _24840.html. dideteksi dan ditangani secara dini, sehingga kelahiran dengan BBLR dapat di minimalisir.

\section{KESIMPULAN DAN SARAN}

Ada hubungan yang signifikan antara usia kehamilan, paritas, kadar HB, preeklampsi, eklampsi, kehamilan ganda dan pendidikan ibu terhadap kejadian BBLR. Tidak ada hubungan signifikan antara usia ibu, diabetes mellitus, jenis kelamin bayi dan pekerjaan ibu dengan kejadian BBLR. Variabel yang paling dominan mempengaruhi kejadian BBLR adalah usia kehamilan (OR=77,055;95\%CI 50,276-118,099)

Saran dari penelitian ini adalah sebagai berikut:

Perlunya dikembangkan model deteksi dini BBLR tingkat komunitas dengan merujuk pada faktor risiko yang ditemukan pada setiap unit pelayanan di Kota Palembang. Mengoptimalkan pelayanan antenatal secara komprehensif, terpadu dan berkualitas agar adanya masalah kesehatan/penyakit penyerta kehamilan dapat dideteksi dan ditangani secara dini. Peningkatan promosi kesehatan pendewasaan usia pernikahan dan saat kehamilan >20 tahun. Peningkatan pengetahuan dan keterampilan petugas kesehatan dalam deteksi dini faktor risiko BBLR di semua tingkat layanan yang terintegrasi dengan model perawatan antenatal terpadu. Bagi peneliti selanjutnya sebaiknya dapat melanjutkan penelitian sejenis dengan variabel yang berbeda seperti status gizi, pemeriksaan ANC, faktor genetik, serta menambahkan dengan analisis kualitatif.

2. Lee ACC, Katz J, Blencowe H. Born too small: national and regional estimates of term and preterm small-for-gestationalage in 138 low-income and middleincome countries in, Lancet Glob Health, in press, 2010. 
3. Muglia LJ, Katz M, The Enigma of Spontaneous Preterm Birth, N Engl J Med, 2010 ; 362(6):529-35.

4. Barros, F.C., Barros, A.J, Villar J. How many low birthweight babies in low- and middle-income countries are preterm? Rev Saude Publ, 2011 ; 45(3): 607-16.

5. Kim D, Saada A. The social determinants of infant mortality and birth outcomes in western developed nations: a crosscountry systematic review, Int $\mathrm{J}$ Environ Res Public Health, 2013;10(6):2296-335, doi:10,3390/ ijerph10062296.

6. Liu, L, et al,. "Global, regional and national causes of child mortality: an updated, systematic analysis for 2010 with time trends since 2000," The Lancet, 2012 Vol, 379, No, 9832, pp, 2151-2161.

7. Katz J, Lee ACC, Kozuki N, Lawn JE and the CHERG, Small-for-Gestational-AgePreterm Birth Working Group. Mortality risk in preterm and small-for-gestationalage infants in low-income and middleincome countries: a pooled country analysis, Lancet, 2013382 (9890): 417 425.

8. UNICEF, Global Nutritions Database, Low birth weight, 2012 http://data,unicef,org/nutrition/lowbirthweight.

9. UNICEF. Improving child nutrition the achievable imperative for global progress. 2013

http://www, unicef,org/publications/index _68661,html publication date: April 2013 publisher: unicef isbn: 978-92-806-46863.

10. Chaparro C, Oot, L, and Sethuraman, K,. Overview of the Nutrition Situation in Seven Countries in Southeast Asia, 2014. April. Pdf.

11. Villar J, Papageorghiou AT, Knight HE. The preterm birth syndrome: a prototype phenotypic classification, Am J Obstet Gynecol , 2012, 206(2): 119 - 23.

12. DD, Jayant, B, Phalke D, B,Bangal V, Peeyuusha D, Sushen B. Maternal risk factors for low birth weight neonates: a hospital based case-control study in rural area of western maharashtra, India, National Journal of Community Medicine Vol 2 Issue 3 Oktober - Desember 2011 Page 397pISSN : 09763325 eISSN : 2229 6816.
13. Ota E, Ganchimeg T, Morisaki N, Vogel JP, Pileggi C, Ortiz-Panozo E et al, Risk factors and adverse perinatal outcomes among term and preterminfants born small-for-gestational-age: secondary analyses of the WHO Multi-Country Survey on Maternal and Newborn Health, PLoS One, 2014;9(8):e105155, doi:10,1371/journal,pone,0105155.

14. Ricketts, S, A, Murray, E, K, and Schwalberg, R. Reducing low birthweight by resolving risks: Results from Colorado's Prenatal Plus Program, American Journal Public Health, 2005; 57(11):1952-1957.

15. UNICEF. Global Databases, 2014-Low birth http://data,unicef,org/nutrition/lowbirthweight WHO. WHA Global Nutrition Targets 2025:Low Birth Weight Policy Brief. 2012. Pdf

16. Global Nutrition Target 2025 : $30 \%$ reduction of low birth weight. Global Nutrition Report, Actions \& Accountability To Accelerate The World's Progress On Nutrition, 2014pdf.

17. UNICEF. "Statistics by Area/Child Nutrition: Low birthweight. 2013.

18. Departemen Kesehatan (Depkes). Rencana Strategis Nasional "Making Pregnancy Safer" di Indonesia 2001-2010, Jakarta : Departemen Kesehatan RI.2001.

19. RISKESDAS (Riset Kesehatan Dasar) 2013. Badan Penelitian dan Pengembangan Kesehatan Kemenkes RI tahun

2013.www.depkes.go.id/resources/downl oad/general/Hasil\%20Riskesdas\%202013. pdf.

20. Profil Kesehatan Indonesia, 2012 http://www, depkes,go,id/resources/ download/ pusdatin/profil-kesehatan indonesia /profil- kesehatan -indonesia 2012, pdf diakses tanggal 29 Desember 2014.

21. Dinas Kesehatan Kota Palembang, 2013. Data dasar Kesehatan Kota Palembang tahun 2013, dinkes.palembang.go.id/tampung/dokume n/dokumen-106-140.pdf.

22. De Jesus, LC., Pappas, A., Shankaran, S., Li, L., Das, A., Bell, EF., Stoll, B.J., Laptook A,R., Walsh, M.C., Hale, E.C., Newman, NS., Bara, R., Higgins RD,. 
"Outcomes of small for gestational age infants born at \&lt;27 weeks' gestation," The Journal of pediatrics, $2013 \mathrm{Jul}$; 163(1):55-60,e1-3.

23. Litt, J.S., Gerry T.H., Margevicius, S., Schluchter, M., Andreias, L., Hack, M., Academic achievement of adolescents born with extremely low birth weight, Acta Paediatr, 2012; 101(12):1240-5.

24. Soleimani, F., Zaheri, F., Abdi, F., LongTerm Neurodevelopmental Outcomes After Preterm Birth, Iran Red Crescent Med J, 2014 June ; 16(6): e17965, DOI: 10,5812/ircmj, 17965.

25. Pantiawati, I., Bayi dengan Berat Badan Lahir Rendah.: Nuha Medika. Yogyakarta 2010.

26. Tjekyan, Suryadi, Faktor risiko dan prognosis Berat Badan Lahir Rendah (BBLR) dan Berat Badan Lahir Sangat Rendah (BBLSR) dan Kejadian Lahir mati di Kota Palembang tahun, Jurnal Kedokteran dan Kesehatan, Publikasi Ilmiah FK Unsri,JKK, 2010 Th. 42, No. 3.

27. Essam, A., El-moselhy, Ibrahim SN., Hamed O. Khalifa, Khadra I. Mohammad,. Low Birth Weights: imaternal risk factors - a Hospital- Based Study in Cairo City, Egypt the Egyptian Journal of Hospital Medicine (Oct 2012) vol., 49: 555- 572 .

28. Resnik, R. MD., Creasy, RK. MD., Chapter 34 - Intrauterine Growth Restriction creasy \& resnik's Maternalfetal medicine Copyright (C) 2010 Elsevier Inc.

29. Martin, J.A., B.E. Hamilton, P.D. Sutton and S.J. Ventura. "Births: Final Data for 2006." National Vital Statistics Reports 2009. 57(7): 1-104.

30. Kurniawati, Leni., Hubungan Pre Eklampsia Dengan Kelahiran Berat Bayi
Lahir Rendah (BBLR) Di RSUD Sragen. Thesis, Universitas Sebelas Maret. Surabaya.2010.

31. WHO. Technical Consultation, 'Towards the development of a strategy for promoting optimal fetal growth', Report of a meeting (Draft), World Health Organization, Geneva. 2004. pdf.

32. Kozuma, S. Approaches to Anemia in Pregnancy. JMAJ 2009; 52(4): 214-218.

33. Depkes RI Gizi Seimbang Menuju Hidup Sehat Bagi Bayi Ibu Hamil dan Ibu Menyusui (Pedoman Petugas Puskesmas). Jakarta: Direktorat Gizi Masyarakat Hal 3-8, Depkes RI. Jakarta. 2002.

34. Waryono. Gizi Reproduksi. Pustaka Rihama; Yogyakarta : 2010 Hal 35-49.

35. Departemen Kesehatan RI (Depkes RI), Ibu Sehat, Bayi Sehat. Jakarta: Direktorat Jendral Pembinaan Kesehatan Masyarakat; Depkes RI. Jakarta 1999.

36. Tazkiah, M., Wahyuni, C,U., Martini S., Epidemiological Determinants Low Birth Weight in Malaria Endemic Areas Banjar District : Departemen Epidemiologi Fakultas Kesehatan Masyarakat Universitas Airlangga Surabaya, Jawa Timur, Indonesia. Jurnal Berkala Epidemiologi, Vol. 1, No. 2 September 2013: 266-276.

37. Simanjuntak, NA., Hubungan Anemia Pada Ibu Hamil dengan Kejadian Bayi Berat Lahir Rendah (BBLR) di Badan Pengelola Rumah Sakit Umum (BPRSU) Rantauprapat Kabupaten Labuhan Batu Tahun 2008 Medan: Fakultas Kesehatan Masyarakat, Universitas Sumatera Utara. 2009 (online) http://repository.usu.ac.id, diakses 19 April 2015).

38. Kleinbaum, DG., Kupper, LL., Muller, K., Applied Regression Analysis and other multivariatable methode.1988. 